\title{
Stok Karbon Pada Tegakan Vegetasi Mangrove Di Pulau Karimunjawa
}

\author{
Ria Azizah Tri Nuraini, Delianis Pringgenies*, Chrisna Adhi Suryono, \\ Vincencius Hendra Adhari
}

\author{
Departemen Ilmu Kelautan, Fakultas Perikanan dan Ilmu Kelautan, Universitas Diponegoro, \\ Jl. Prof. H. Soedarto S.H, Tembalang, Semarang, Jawa Tengah 50275 Indonesia \\ Email: delianispringgeies@lecturer.undip.ac.id
}

\begin{abstract}
Abstrak
Hutan Mangrove merupakan suatu ekosistem laut yang memiliki peran penting sebagai penyimpan karbon tertinggi di wilayah tropis. Fungsi mangrove ini dapat membantu dalam mengurangi emisi karbon dan pemanasan global. Pulau Nyamuk dan Pulau Parang merupakan vegtasi alami yang mengalami penurunan luasan mangrove yang diduga disebabkan oleh alih fungsi lahan, sehingga akan menyebabkan penurunan fungsi mangrove dalam menyerap $\mathrm{CO} 2$. Tujuan dilakukannya penelitian ini adalah menganalisis dan menduga total simpanan karbon dan serapan $\mathrm{CO} 2$ pada tegakan mangrove di Pulau Nyamuk dan Pulau Parang. Manfaat dilakukanya penelitian ini adalah memberikan informasi mengenai manfaat mangrove sebagai penyerap karbon. Pengambilan data yang dilakukan dalam penelitian ini menggunakan purposive sampling method, dimana setiap lokasi memiliki 3 stasiun (Pulau Nyamuk; Sareh Besar, Sareh Kecil, Ujung; Pulau Parang: Batu Merah, Plawangan, Batu Hitam). Setiap stasiun dibagi menjadi 3 plot untuk dilakukan pengambilan data diameter batang mangrove. Data diameter batang mangrove digunakan untuk menghitung nilai biomasssa tegakan dengan menggunakan rumus allometrik dalam menduga simpanan karbon pada tegakan mangrove suatu area. Hasil penelitian menunjukan bahwa simpanan total karbon pada tegakan mangrove di Pulau Nyamuk memiliki nilai 1.176,48 ton/ha, yang dibagi sebagai berikut: Stsiun Sareh Kecil: 383,16 ton/ha, Stasiun Sareh Besar: 419,51 ton/ha, dan Stasiun Ujung: 373,81 ton/ha, sedangkan di Pulau Parang memiliki nilai 2009.031 ton/ha, yang dibagi sebagai berikut: Stasiun Batu Merah 767,672 ton/ha, Stasiun Batu Hitam 654,444 ton/ha, dan Stasiun Plawangan 586,915.
\end{abstract}

Kata kunci: Simpanan Karbon, Serapan Karbon, Mangrove, Tegakan

\section{Abstract \\ Carbon stock in vegetation stands on the island of Karimunjawa}

Mangrove Forest is a marine ecosystem that has an important role as the highest carbon storage in the tropics. This mangrove function can help in reducing carbon emissions and global warming. Nyamuk Island and Parang Island are natural vegetation which decrease mangrove area which is caused by land conversion function, so it will cause mangrove function to absorb $\mathrm{CO}_{2}$. The purpose of this research is to analyze and estimate total carbon storage and $\mathrm{CO}_{2}$ uptake on mangrove stands in Nyamuk Island and Parang Island. The benefit of this research is to provide information about the benefits of mangroves as carbon sinks. The data collected in this research using purposive sampling methods, where each location has 3 stations (Nyamuk Island: Sareh Besar, Sareh Kecil, Ujung; Parang Island: Batu Merah, Plawangan, Batu Hitam). Each station is divided into 3 plots for data collection of mangrove stems diameter. The mangrove stem diameter data were used to calculate the stand biomass value by using allometric formula in estimating carbon stock in the mangrove stand of an areas. The results of research, that total carbon deposits in mangrove stands in Nyamuk Island had a value of 1,176.48 tons/ha, divided as follows: Sareh Kecil Station: 383.16 tons/ha, Sareh Besar Station: 419.51 tons/ha, and Ujung Station: 373,81 ton/ha, while in Parang Island has value 2009.031 ton/ha, which is divided as follows: Batu Merah Station 767,672 ton/ha, Batu Hitam Station 654,444 ton/ha, and Plawangan Station 586,915.

Keywords: Carbon Deposits, Carbon Sinks, Mangrove, Stands 


\section{PENDAHULUAN}

Meningkatnya konsentrasi gas yang ada diatmosfer seperti gas karbon dioksida (CO2), gas metana $(\mathrm{CH} 4)$, dan gas nitrogen oksida $(\mathrm{N} 2 \mathrm{O})$, dapat memicu terjadinya pemanasan global sehingga secara tidak langsung akan mengganggu seluruh aktivitas yang ada alam, hal ini disebabkan karena banyaknya emisi - emisi gas karbon dioksida (CO2) yang berasal dari pengaruh Gas Rumah Kaca (GRK) (Imiliyana et al., 2011). Konsentrasi Gas Rumah Kaca (GRK) yang ada dilapisan atmosfer bumi semakin waktu semakin meningkat. Salah satunya disebabkan oleh kurang tepatnya pengelolaan lahan yang dijadikan sebagai bangunan - bangunan berbasis gas rumah kaca dengan mengesampingkan kondisi lingkungan, proses pengelolaan lahan yang dilakukan yaitu dengan cara menebang hutan dengan skala yang luas (Hairiah et al., 2001). Hutan mangrove merupakan salah satu ekosistem yang termasuk dalam ekosistem tumbuhan tingkat tinggi, sehingga hutan mangrove ini memiliki kemampuan yang baik dalam beradaptasi karena letak hutan mangrove itu sendiri yang berada pada daerah yang terkena pasang surut dan gelombang air laut yang cukup tinggi (Alongi et al., 2004). Hutan mangrove merupakan sarana dalam solusi permasalahan ini, karena dapat membantu kualitas atmosfer, namun proses penebangan vegetasi mangrove berskala luas (deforestasi) secara global dan perubahan tata guna lahan yang ada diwilayah pesisir terjadi sehingga berdampak pada peningkatan emisi karbon dioksida $\left(\mathrm{CO}_{2}\right)$ sebesar $20 \%$, sehingga menggangu keseimbangan alam (Rahayu, 2007).

Menurut Ati et al. (2014), yang menyatakan bahwa mangrove atau secara umum disebut sebagai hutan mangrove yang memiliki fungsi ekologis sebagai penyerap dan atau penyimpan kandungan karbon. Untuk membuktikan peran hutan mangrove tersebut, maka dibutuhkan lokasi ekosistem yang alami seperti mangrove yang terdapat di pulau Nyamuk dan Pulau Parang Karimunjawa, Jawa tengah (Kartijono et al., 2010) dan Hartoko et al. (2013). Luasan mangrove di Pulau Parang yang berada di Batu Hitam, Batu merah dan Legon Ipik mengalami penurunan luasan, dari data pemetaan luasan mangrove terakhir di Pulau Parang menyebutkan pada tahun 1997 area mangrove seluas 46,80 Ha, kemudian pada tahun 2004 turun menjadi 41,44 Ha, dan pada tahun 2011 mengalami penurunan menjadi 38,36 $\mathrm{Ha}$, dan apabila dikalkulasikan maka dari tahun 1994 sampai dengan tahun 2011 penurunan luasan mangrove sebesar 18,03\% (Hartoko et al., 2013). Proses penebangan pohon (deforestasi) yang terjadi dapat berdampak buruk dan terhadap fungsi ekologis vegetasi mangrove, fungsi ekologis vegetasi mamgrove yang dimaksud adalah sebagai tempat untuk mencari makan, tempat untuk memijah, dan tempat untuk berkembang biak dari biota, seperti udang, ikan, kerang, dan beberapa jenis biota lainnya, fungsi - sungsi tersebut akan terganggu jika terjadi penebangan vegetasi mangrove. Selain itu fungsi dari vegetasi. Berdasarkan hal tersebut, maka tujuan penelitian adalah untuk mengetahui: simpanan karbon pada tegakan vegetasi mangrove, serapan karbon pada tegakan vegetasi mangrove dan korelasi antara simpanan karbon dan serapan karbon pada tegakan vegetasi mangrove di Pulau Nyamuk dan Pulau Parang.

\section{MATERI DAN METODE}

Materi digunakan adalah simpanan karbon pada tegakan vegetasi mangrove yang meliputi DBH (Diameter Breast High) yang ada di Pulau Nyamuk dan Pulau Parang, Karimunjawa, Kabupaten Jepara-Jawa Tengah. Sedang data sekunder yang dibutuhkan dalam penelitian ini adalah data kerapatan, data struktur komposisi vegetasi mangrove, dan data simpanan karbon di substrat vegetasi mangrove.

\section{Metode Penentuan Lokasi}

Metode yang dilakukan dalam menentukan lokasi penelitian ini menggunakan metode pertimbangan atau yang sering disebut sebagai purposive sampling methods. Purposive Sampling Methods merupakan metode pengambilan sampel yang dilakukan dengan melakukan pemilihan lokasi sesuai dengan ciri - ciri spesifik dan karakteristik tertentu, yang relevan dengan kebutuhan dari penelitian tersebut dilakukan (Djarwanto dan Pangestu, 1998) Gambar 1. menunjukkan lokasi penelitian yang di Pulau Nyamuk (gambar kiri) dan Pulau Parang (gambar kanan), selain menunjukan lokasi penelitian Gambar 1. juga menunjukan letak stasiun di setiap lokasinya, stasiun yang ada di Pulau Nyamuk antara lain Ujung, Sareh Kecil dan Sareh Besar (dari utara ke selatan), sedanglkan stasiun yang ada di Pulau Parang antara lain Batu Hitam, Batu Merah dan Plawangan (dari utara ke selatan). 


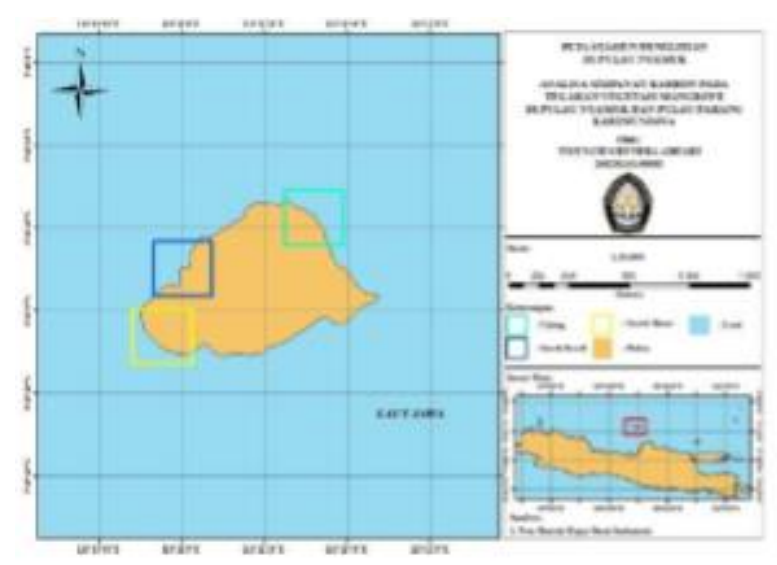

Pulau Nyamuk

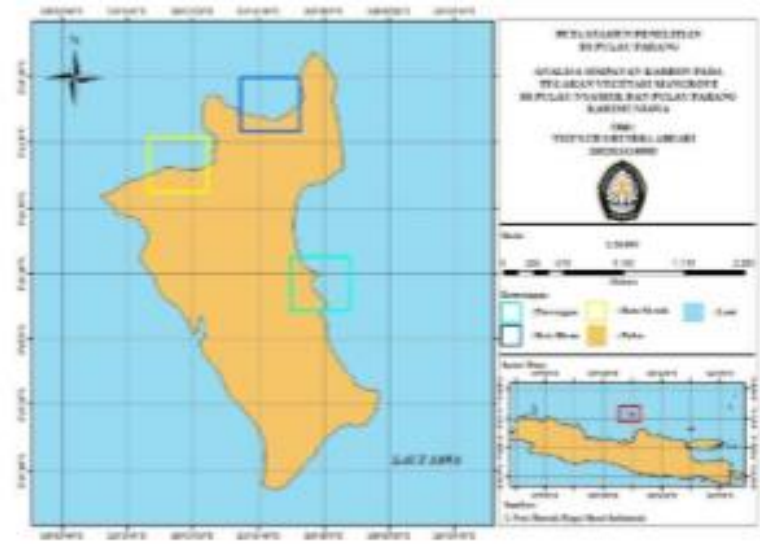

Pulau Parang

Gambar 1. Lokasi dan Stasiun Penelitian Analisa Simpanan Karbon pada Tegakan Vegetasi Mangrove di Pulau Nyamuk dan Pulau Parang, Karimunjawa

Pengambilan data jenis mangrove di setiap stasiun di lokasi Pulau Nyamuk dan Pulau Parang menggunakan acuan Kitamura et al., (1997), Ashton dan Macintosh, (2002) dan Cintron and Novelli (1984). Data pohon yang diambil dilakukan dalam plot $10 \mathrm{~m} \times 10 \mathrm{~m}$ dengan diameter batang diukur pada ketinggian setinggi dada (Diameter at Breast Height) (dbh) atau $\pm 1,3 \mathrm{~m}$. Kategori pohon yang diambil memiliki $\mathrm{dbh} \geq 4 \mathrm{~cm}$ meliputi jumlah tegakan, diameter, dan spesies dalam plot (Ashton \& Macintosh, 2002).

Pengambilan data diameter tegakan dilakukan dengan menggunakan metode DBH (Diameter at Breast High), metode ini digunakan untuk vegetasi mangrove kategori pohon yang pengukurannya dihitung sekitar tinggi dada orang dewasa atau sekitar 1,3 meter dari tanah, kenyataan di lapangan sulit untuk menentukan diameter batang vegetasi mangrove kategori pohon dengan tepat, maka dengan adanya keuslitan yang ada dilapangan tersebut digunakanlah acuan berdasarakan Cintron \& Novelli (1984).

Perhitungan karbon yang dilakukan memilih untuk menggunakan prosedur pengukuran biomassa pohon yang dilakukan dengan cara non destructive (tidak merusak induvidu mangrove) dengan catatan jenis tanaman yang diukur sudah diketahui rumus allometriknya. Rumus allometrik ini merupakan rumus yang digunakan dengan menduga estimasi kandungan yang ada di bagian pohon atau bagian atas (aboveground biomass). Adapun rumus atau perhitungan yang dilakukan, peneliti menggunakan acuan dari Komiyama et al. (2005). Setelah didapat hasil biomassa tegakan mangrove dilanjutkan perhitungan densitas biomassa tegakan dalam 1 petak stasiun, 1 petak stasiun yang digunakan peneliti berukuran $10 \times 10$ m (Brown, 1997). Selanjutnya, Perhitungan Serapan CO2 menggunakan persamaan rumus Brown (1997) dan International Panel of Climate Change, yang kemudian dirumuskan menjadi persamaan sebagai berikut: Karbon Dioksida $=$ 3,67 x D Ktop, dengan catatan. Karbon Dioksida adalah jumlah serapan karbon $\mathrm{CO} 2$ dan D Ktop adalah Total karbon tegakan di lokasi penelitian (ton/ha).

Parameter kualitas lingkungan yang diambil pada penelitian ini meliputi suhu, $\mathrm{pH}$, dan salinitas. Pengambilan data kualitas lingkungan ini, dilakukan secara langsung di lapangan atau secara in situ dan di setiap stasiun dilakukan 3 kali pengulangan untuk mendapatakan hasil yang akurat, kualitas lingkungan yang diambil menggunakan alat thermometer, kertas $\mathrm{pH}$, dan refraktometer.

\section{HASIL DAN PEMBAHASAN}

Hasil dari pengambilan data parameter lingkungan yang ada dilokasi menunjukan nilai rata - rata suhu udara di Pulau Nyamuk $27-29^{\circ} \mathrm{C}$, suhu substrat $26-28^{\circ} \mathrm{C}$, dengan nilai $\mathrm{pH}$ tanah adalah 6, dan dengan nilai salinitas 34-35\%, sedangkan untuk parameter lingkungan yang berada di Pulau Parang nilai rata - rata suhu udara $27-30^{\circ} \mathrm{C}$, suhu substrat $27-31^{\circ} \mathrm{C}$, dengan nilai $\mathrm{pH}$ 6 , dan nilai salinitas 34-35\%. Nilai dari diameter tegakan yang didapat, telah dilakukan perhitungan, nilai tersebut akan menghasilkan nilai dari biomassa atau energi yang tersimpan pada tegakan mangrove itu sendiri, data yang digunakan menggunakan nilai dari 
diameter tegakan di lokasi Pulau Nyamuk dan Pulau Parang. (Tabel 1 dan Tabel 2).

Selain dapat disajikan dalam bentuk tabel, hasil dari biomassa tegakan mangrove dalam suatu area dapat disajikan dalam bentuk grafik, grafik hasil yang dimaksud akan memperlihatkan perbedaan jumlah biomassa tegakan mangrove setiap stasiun, sehingga akan terlihat jarak antara jumlah biomassa tegakan mangrove dari stasiun satu dengan stasiun yang lain.

Tabel 1. Biomassa Tegakan Mangrove di Pulau Nyamuk

\begin{tabular}{clrcr}
\hline Stasiun & \multicolumn{1}{c}{ Spesies } & Ni & \multicolumn{1}{c}{$\begin{array}{c}\text { DBH } \\
(\mathrm{cm})\end{array}$} & $\begin{array}{r}\text { Biomassa Tegakan } \\
(\mathrm{kg})\end{array}$ \\
\hline Sareh Besar & Brugueira gymnorrhiza & 6 & $8,1-31,5$ & 2216,61 \\
& Rhizophora mucronata & 32 & $5,4-26$ & 4323,90 \\
& Rhizophora lamarckii & 2 & $16,2-27,7$ & 47,39 \\
& Rhizophora stylosa & 7 & $5,1-19,4$ & 699,56 \\
& Total & 47 & & 7287,46 \\
Sareh Kecil & Bruguiera gymnorrhiza & 10 & $5,0-44,9$ & 2889,28 \\
& Ceriops tagal & 1 & $6,5-6,5$ & 22,22 \\
& Rhizophora lamarkii & 50 & $5,2-18,5$ & 2937,37 \\
& Rhizophora stylosa & 17 & $5,2-21,3$ & 1916,92 \\
& Total & 78 & & 7765,79 \\
Ujung & Bruguiera gymnorrhiza & 2 & $6,5-7,3$ & 50,76 \\
& Rhizophora stylosa & 50 & $5,5-41$ & 7442,14 \\
& Total & 52 & & 7492,90 \\
\hline
\end{tabular}

Keterangan: $\mathrm{Ni}=$ Jumlah pohon dalam suatu area (ind), $\mathrm{DBH}=$ Diameter at Breast High

Tabel 2. Biomassa Tegakan Mangrove di Pulau Parang

\begin{tabular}{|c|c|c|c|c|}
\hline Stasiun & Spesies & $\mathrm{Ni}$ & DBH & Biomassa Tegakan $(\mathrm{kg})$ \\
\hline \multirow[t]{4}{*}{ Batu Merah } & Bruguiera gymnorrhiza & 20 & $5-46,8$ & 5182,88 \\
\hline & Rhizophora apiculata & 1 & $4,9-4,9$ & 11,03 \\
\hline & Rhizophora mucronata & 75 & $5-56,5$ & 10277,49 \\
\hline & Total & 96 & & 15471,41 \\
\hline \multirow[t]{9}{*}{ Batu Hitam } & Bruguiera cylindica & 4 & $5,8-15$ & 372,23 \\
\hline & Ceriops tagal & 1 & $13,1-13,1$ & 123,61 \\
\hline & Excoecaria agallocha & 3 & $15,9-26,4$ & 554,46 \\
\hline & Sonneratia ovata & 8 & $7,2-26,4$ & 720,00 \\
\hline & Xylocarpus mollucensis & 7 & $6,8-20,1$ & 829,67 \\
\hline & Bruguiera gymnorrhiza & 4 & $14-34,1$ & 2792,59 \\
\hline & Rhizophora lamarkii & 1 & $5,5-5,5$ & 15,63 \\
\hline & Rhizophora mucronata & 19 & $5-35,67$ & 6394,63 \\
\hline & Total & 47 & & 11802,83 \\
\hline \multirow[t]{3}{*}{ Plawangan } & Bruguiera gymnorrhiza & 22 & $5,4-33,4$ & 3978,23 \\
\hline & Rhizophora mucronata & 38 & $5,1-30,9$ & 12182,94 \\
\hline & Total & 60 & & 16161,17 \\
\hline
\end{tabular}

Keterangan: $\mathrm{Ni}=$ Jumlah pohon dalam suatu area (ind), $\mathrm{DBH}=$ Diameter at Breast High 


\section{Simpanan Karbon Tegakan di Pulau Nyamuk dan Pulau Parang}

Hasil perhitungan biomassa tegakan mangrove yang telah dihitung, kemudian akan dilanjutkan dengan menghitung simpanan karbon pada tegakan yang ada di vegetasi mangrove, perhitungan ini merupakan perhitungan lanjutan dari hasil biomassa tegakan mangrove yang telah disajikan pada tabel dan grafik sebelumnya, data yang digunakan merupakan data biomassa tegakan mangrove di lokasi Pulau Nyamuk dan Pulau Parang. Nilai simpanan karbon pada tegakan yang telah dihitung akan memiliki satuan hitungan ton/ha, sehingga akan dapat diperkirakan serapan total karbon tegakan mangrove yang ada disuatu area dengan luasan hektar. Hasil yang didapat dari perhitungan ini, disajikan pada Tabel 3. untuk lokasi penelitian di Pulau Nyamuk.

\section{Serapan $\mathrm{CO}_{2}$ Tegakan Mangrove di Pulau Nyamuk dan Pulau Parang}

Hasil dari perhitungan nilai total karbon tegakan vegetasi mangrove yang telah dihitung, kemudian dilanjutkan dengan mengalikan hasil total karbon tegakan mangrove tersebut dengan nilai 3,67. Hasil nilai serapan karbon dioksida $\left(\mathrm{CO}_{2}\right)$ di Pulau Nyamuk dan Pulau parang (Tabel $5)$.

Tabel 3. Simpanan Karbon pada Tegakan di Pulau Nyamuk

\begin{tabular}{lcc}
\hline Spesies & Stasiun & Simpanan Karbon (Ton/Ha) \\
\hline Brugueira gymnorrhiza & Sareh Besar & 110,83 \\
Rhizophora mucronata & & 269,15 \\
Rhizophora lamarckii & 2,37 \\
Rhizophora stylosa & 34,98 \\
Total & 417,33 \\
Bruguiera gymnorrhiza & 144,46 \\
Ceriops tagal & 1,11 \\
Rhizophora lamarkii & 146,87 \\
Rhizophora stylosa & 95,85 \\
Total & 388,29 \\
Bruguiera gymnorrhiza & 2,54 \\
Rhizophora stylosa & Ujung & 372,11 \\
Total & & 374,64 \\
\hline
\end{tabular}

Tabel 4. Simpanan Karbon pada Tegakan di Pulau Parang

\begin{tabular}{llc}
\hline Stasiun & Spesies & Simpanan Karbon (Ton/Ha) \\
\hline Batu Merah & Bruguiera gymnorrhiza & 259,14 \\
& Rhizophora apiculata & 0,55 \\
& Rhizophora mucronata & 513,87 \\
Total & 773,57 \\
& Bruguiera cylindica & 18,61 \\
& Ceriops tagal & 123,61 \\
& Excoecaria agallocha & 27,72 \\
& Sonneratia ovata & 36,00 \\
& Xylocarpus mollucensis & 41,48 \\
& Bruguiera gymnorrhiza & 139,63 \\
& Rhizophora lamarkii & 0,78 \\
& Rhizophora 184ucronate & 319,73 \\
& Total & 707,57 \\
& Bruguiera gymnorrhiza & 198,91 \\
& Rhizophora 184ucronate & 609,15 \\
\hline
\end{tabular}


Tabel 5. Serapan CO2 Tegakan Mangrove di Pulau Nyamuk

\begin{tabular}{llr}
\hline Stasiun & Spesies & Serapan Karbon (Ton/Ha) \\
\hline Sareh Besar & Brugueira gymnorrhiza & 406,75 \\
& Rhizophora mucronata & 987,79 \\
& Rhizophora lamarckii & 8,70 \\
& Rhizophora stylosa & 128,37 \\
& Total & 1531,60 \\
Sareh Kecil & Bruguiera gymnorrhiza & 530,18 \\
& Ceriops tagal & 4,08 \\
& Rhizophora lamarkii & 539,01 \\
& Rhizophora stylosa & 351,75 \\
& Total & 1425,02 \\
Ujung & Bruguiera gymnorrhiza & 9,32 \\
& Rhizophora stylosa & 1365,63 \\
\hline
\end{tabular}

Tabel 6. Serapan CO2 Tegakan Mangrove di Pulau Parang

\begin{tabular}{clc}
\hline Stasiun & \multicolumn{1}{c}{ Spesies } & Serapan Karbon (Ton/Ha) \\
\hline Batu Merah & Bruguiera gymnorrhiza & 951,06 \\
& Rhizophora apiculata & 2,02 \\
& Rhizophora mucronata & 1885,92 \\
& Total & 2839,00 \\
& Bruguiera cylindica & 68,31 \\
& Ceriops tagal & 22,68 \\
& Excoecaria agallocha & 101,74 \\
& Sonneratia ovata & 132,12 \\
& Xylocarpus mollucensis & 152,24 \\
& Bruguiera gymnorrhiza & 512,44 \\
& Rhizophora lamarkii & 2,87 \\
& Rhizophora mucronata & 1173,41 \\
& Total & 2165,82 \\
& Bruguiera gymnorrhiza & 730,00 \\
& Rhizophora mucronata & 2235,57 \\
\hline
\end{tabular}

\section{Hubungan Korelasi antara Serapan dan Simpanan Karbon}

Hasil korelasi antara serapan karbon dan simpanan karbon yang ada di tegakan mangrove menghasilkan nilai koefisien adalah 0,97 , sehingga dapat dinyatakan bahwa adanya hubungan positif yang erat antara serapan karbon dengan simpanan karbon pada tegakan mangrove. Hasil dari korelasi tersebut dapat dilihat pada Tabel 7.
Hasil parameter kualitas lingkungan salinitas dari vegetasi mangrove di Pulau Nyamuk bernilai 35$40 \mathrm{ppt}$, jenis mangrove yang ada di lokasi ini antara lain Brugueira gymnorrhiza, Rhizophora mucronata, Rhizophora lamarckii, Rhizophora stylosa, dan Ceripos tagal. Selain salinitas, faktor lain seperti suhu dan $\mathrm{pH}$ merupakan faktor yang dapat mempengaruhi pertumbuhan dari mangrove itu sendiri. Menurut Saparinto (2007), suhu ideal yang dibutuhkan mangrove untuk tumbuh dengan 
baik yaitu $25-36^{\circ} \mathrm{C}$, hal ini ditambahkan oleh Kennish (1990) yang menyatakan bahwa vegetasi mangrove dapat menolerir suhu yang lebih dari $20^{\circ} \mathrm{C}$ dan kurang dari $5^{\circ} \mathrm{C}$, namun vegetasi mangrove akan mengalami kerusakan atau tidak dapat tumbuh dengan baik pada suhu $-4{ }^{\circ} \mathrm{C}$, hasil parameter kualitas lingkungan suhu di lokasi penelitian ini bernilai $27-29{ }^{\circ} \mathrm{C}$, dan untuk parameter kualitas lingkungan $\mathrm{pH}$ nilai yang didapat dari lokasi ini bernilai 6 , untuk hasil parameter kualitas lingkungan salinitas dari vegetasi mangrove di Pulau Parang bernilai \pm 38 $40 \mathrm{ppt}$, jenis - jenis mangrove yang tumbuh di lokasi ini antara lain $B$. gymnorrizha, $R$. mucronata, B. cylindrica, E. agallocha, S. ovata, dan R. lamarckii.

Hasil simpanan karbon tegakan pada vegetasi mangrove di Pulau Nyamuk adalah 1.180,26 ton/ha, dan untuk Pulau Parang adalah $2.289,2$ ton/ha, dari total keseluruhan simpanan karbon dalam suau area, terdapat beberapa faktor yang membedakan antara satu dengan yang lainnya.

Hasil perhitungan kerapatan vegetasi mangrove yang ada di Pulau Nyamuk dan Pulau Parang, merupakan hasil penelitian dari Mahbub Murtiyoso yang hasil tersebut. Kerapatan pohon merupakan salah satu faktor yang mempengaruhi banyak sedikitnya simpanan karbon dalam bentuk biomassa, hal ini didukung oleh pernyataan Hairiah \& Rahayu (2007), yang menyatakan bahwa potensi simpanan karbon tegakan akan dipengaruhi oleh kerapatan vegetasi mangrove yang ada di lokasi tertentu. Hasil simpanan karbon di Pulau Nyamuk dan Pulau Parang menunjukan kerapatan tidak begitu berpengaruh dengan jumlah total karbon tegakan yang ada di setiap stasiunnya, hal yang dibuktikan hanya di stasiun Batu Hitam dengan kerapatan 1833 ind/ha memiliki nilai simpanan karbon terendah di lokasi Pulau Parang dengan nilai 707,57 ton/ha. Sedangkan di stasiun lain kerapatan tidak begitu berpengaruh untuk jumlah simpanan karbon yang ada, namun ada hal lain seperti kerapatan kayu yang akan mempengaruhi simpanan karbon.

Tabel 7. Korelasi Serapan Karbon dan Simpanan Karbon Mangrove

\begin{tabular}{lc}
\hline Serapan Karbon & Simpanan Karbon \\
Serapan Karbon & 1 \\
Simpanan Karbon & 0,968881968 \\
\hline
\end{tabular}

Menurut Santini et al. (2012) yang menyatakan perbedaan kerapatan kayu akan mempengaruhi pertumbuhan dari jenis mangrove pada suatu area. Nilai kerapatan di Stasiun Batu Merah bernilai 3567 ind/ha, dengan jumlah simpanan karbon pada tegakan 773,57 ton/ha, nilai kerapatan di Stasiun Plawangan bernilai 2000 ind/ha yang memiliki total karbon tegakan 808,06 ton/ha.

Nilai kerapatan setiap stasiun yang ada di Pulau Nyamuk antara lain sebagai berikut: Stasiun Sareh Besar memiliki nilai kerapatan 1567 ind/ha, dengan jumlah simpanan karbon pada tegakan bernilai 417,33 ton/ha, Stasiun Sareh Kecil memiliki nilai kerapatan 2600 ind/ha, dengan jumlah simpanan karbon pada tegakan bernilai 388,29 ton/ha, dan di Stasiun Ujung memiliki nilai kerapatan $2000 \mathrm{ind} / \mathrm{ha}$, dengan jumlah simpanan karbon pada tegakan bernilai 808,06 ton/ha, dari pernyataan Hairiah \& Rahayu (2007) yang menyatakan bahwa kerapatan mempengaruhi jumlah total karbon tegakan tidak dapat menjadi dasar pada stasiun ini, karena penelitian ini menemukan bahwa selain dari kerapatan jumlah total karbon tegakan juga dipengaruhi oleh ukuran diameter dari suatu pohon dan dipengaruhi juga oleh kerapatan kayu (wood density) dari jenis mangrove itu sendiri, kerapatan kayu dapat mempengaruhi perhitungan dan pertumbuhan dari jenis mangrove itu sendiri, semakin besar nilai kerapatan kayu (wood density) pada satu jenis mangrove, maka akan semakin lama pula jenis mangrove tersebut akan tumbuh, sehingga dengan lamanya proses pertumbuhan suatu jenis mangrove, maka akan mempengaruhi ukuran dari diameter batang jenis mangrove tersebut, dan akhirnya akan mempengaruhi jumlah total karbon yang ada pada tegakan suatu jenis mangrove itu sendiri, dalam penelitian ini dapat dicontohkan Stasiun Sareh Besar yang memiliki kerapatan rendah dan Sareh Kecil yang memiliki jenis kerapatan yang tinggi, selain kerapatan vegetasi yang berbeda stasiun ini memiliki berbedaan seperti dari ukuran diameter pohon, spesies mangrove yang tumbuh, dan jumlah pohon mangrove yang tumbuhan di setiap stasiunnya. Jenis mangrove yang tumbuh dan mempengaruhi jumlah serapan karbon, di Stasiun Sareh Besar adalah spesies mangrove Rhizophora mucronata, dan di Stasiun Sareh Kecil adalah spesies mangrove Ceriops tagal yang tumbuh. 2 spesies mangrove ini dapat berdampak secara langsung untuk simpanan karbon pada tegakan vegetasi 
mangrove, karena 2 jenis mangrove ini memiliki nilai kerapatan kayu yang berbeda, sehingga akan mempengaruhi pertumbuhan dan daya simpan karbon di suatu vegetasi mangrove.

Spesies R. mucronata merupakan spesies mangrove yang memiliki kerapatan kayu 0,8483 $\mathrm{gr} / \mathrm{cm}^{3}$, sedangkan untuk spesies $C$. tagal memiliki nilai kerapatan kayu $0,8859 \mathrm{gr} / \mathrm{cm}^{3}$, perbedaan spesies mangrove inilah yang membuat pernyataan dari Hairiah \& Rahayu (2007) yang menyatakan kerapatan mangrove mempengaruhi jumlah total karbon tegakan di suatu area, tidak sesuai dengan hasil dari lokasi penelitian yang ada di Pulau Nyamuk. Perbandingan dari nilai simpanan karbon tegakan di Pulau Nyamuk dan Pulau Parang sangat signifikan, hal ini ditunjukan dari jumlah total karbon tegakan yang ada di Pulau Parang jauh lebih banyak dibandingkan dengan yang ada di Pulau Nyamuk, hal ini disebabkan karena jenis mangrove yang tumbuh di lokasi Pulau Parang diduga pertumbuhannya lebih cepat dibandingkan dengan jenis mangrove yang tumbuh di Pulau Nyamuk.

Selain dari tegakan mangrove simpanan karbon yang ada di substrat menjadi data pelengkap simpanan keseluruhan karbon pada vegetasi mangrove di Pulau Nyamuk dan Pulau Parang, Karimunjawa. Hasil penelitian dari Tito Barudin menunjukan bahwa simpanan karbon substrat dipengaruhi oleh adanya proses dikomposisi dan intrusi air laut yang ada di lokasi penelitian, hasil simpanan karbon substrat yang ada di lokasi penelitian.

Serapan $\mathrm{CO}_{2}$ atau karbon dioksida merupakan hasil dari kemampuan mangrove dalam menyerap $\mathrm{CO}_{2}$ di atmosfer yang digunakan sebagai bahan fotosintesis, sehingga akan berdampak langsung terhadap banyak sedikitnya konsentrasi $\mathrm{CO}_{2}$ di atmosfer. Hasil dari perhitungan $\mathrm{CO}_{2}$ ini menunjukan hasil yang berbanding lurus terhadap lurus dengan hasil simpanan karbon tegakan yang ada di vegetasi mangrove. Menurut Afdal (2007), mangrove memiliki kemampuan besar untuk menyerap $\mathrm{CO}_{2}$ di atmosfer, yang dimanfaatkan untuk bahan fotosintesis. Proses fotosintesis ini dilakukan daun - daun mangrove, sehingga akan mempengaruhi hasil serapan $\mathrm{CO}_{2}$ pada suatu area di vegetasi mangrove.

Hasil serapan $\mathrm{CO}_{2}$ di Pulau Nyamuk dan Pulau Parang memiliki perbedaan yang cukup signifikan, hasil berbeda ketika kerapan mangrove dalam induvidu per satuan area dikelompokan menjadi satu, sehingga akan terlihat perbedaan yang jelas pada stasiun yang memiliki kerapatan lebat, hal ini dipengaruhi dari tutupan kanopi mangrove yang ada di stasiun tersebut. Besarnya kerapatan mangrove tidak berbanding lurus terhadap presentasi tutupan kanopi mangrove, sehingga dengan demikian hasil serapan $\mathrm{CO}_{2}$ dipengaruhi oleh besarnya tutupan kanopi mangrove.

Hasil serapan $\mathrm{CO}_{2}$ ini, dapat dilihat dari hasil simpana karbon pada tegakan dan rimbunnya daun yang tumbuh yang berasal dari besarnya tutupan kanopi di setiap stasiun. Berdasarkan hasil perhitungan tutupan kanopi yang dilakukan oleh Mahbub Murtiyoso, hasil tutupan kanopi yang ada di Lokasi Pulau Nyamuk adalah sebagai berikut: stasiun Sareh Besar memiliki nilai $75 \%$ tutupan kanopi, stasiun Sareh Kecil memiliki nilai $62 \%$ tutupan kanopi dan stasiun Ujung $53 \%$, sedangkan nilai tutupan kanopi di lokasi Pulau Parang adalah stasiun Batu Merah memiliki nilai $62 \%$ tutupan kanopi, stasiun Plawangan memiliki nilai $78 \%$ tutupan kanopi, dan stasiun Batu Hitam memiliki nilai $88 \%$ tutupan kanopi. Dari hasil penelitian tersebut, dapat mendukung hasil serapan karbon yang ada di lokasi Pulau Nyamuk dan Pulau Parang

\section{KESIMPULAN}

Nilai simpanan karbon pada tegakan pada vegetasi mangrove di Pulau Nyamuk adalah 1180,26 ton/ha, dan nilai simpanan karbon pada tegakan pada vegetasi mangrove di Pulau Parang adalah 2289.2 ton/ha. Nilai hasil penelitian yang telah dilakukan, nilai serapan karbon pada tegakan pada vegetasi mangrove di Pulau Nyamuk adalah 4331,57 ton/ha, dan nilai serapan karbon pada tegakan pada vegetasi mangrove di Pulau Parang adalah 7.970,40 ton/ha. Korelasi antara serapan karbon dengan simpanan karbon pada tegakan vegetasi mangrove memiliki hubungan positif dengan nilai koefisien 0,97 .

\section{DAFTAR PUSTAKA}

Afdal. 2007. Siklus Karbon dan Karbon Dioksida di Atmosfer dan Samudera. Oseana, 32(2):2941

Alongi, D.M., Sasekumar, A., Chong, V.C., Pfitzner, J., Trott, L.A., Tirendi, F., Dixon, P., \& Bruskill, G.J. 2004. Sediment Accumulation and Organic Material Flux in a Managed Mangrove Ecosystem: Estimates of Land-Ocean-Atmosfphere Exchange in Peninsular Malaysia. Marine Geologi. 208: 383-401. 
Ati, R.N.A., Rustam, A., Terry L.K., Nasir, S., Mariska A., August,, D., Peter, M., Hadiwijaya, L.S., \& Andreas A.H. 2014. Stok Karbon dan Struktur Komunitas Mangrove Sebagai Blue Carbon di Tanjung Lesung, Banten. Pusat Penelitian dan Pengembangan Sumberdaya Laut dan Pesisir. 10(2):119-127

Ashton \& Macintosh, 2002. Mangrove Rehabilitation and Intertidal Biodiversity: a Study in the Ranong Mangrove Ecosystem, Thailand. Estuarine, Coastal and Shelf Science, 55(3):331-345

Brown, S. 1997. Estimating Biomass and Biomass Change of Tropical Forest. A Forest Resource Assessment Publik. 134 hlm.

Cintron, G. \& Novelli, Y.S. 1984. Methods for Studying Mangrove Structure in editor Snedaker, S.C \& Snedaker, J.S. The Mangrove Ecosystem: Research Methods. UNESCO. Paris.

Djarwanto, P.S. \& Pangestu, S. 1998. Statistik Induktif, BPFE, Jakarta

Hairiah, K., \& Rahayu, S. 2007. Pengukuran "Karbon Tersimpan" di berbagai Macam Penggunaan Lahan. World Agroforesty centre - ICRAF, SEA Regional Office. Universitas Briwijaya; $77 \mathrm{p}$.

Hairiah, K., S. M. Sitompul, M. V. Noordwijk, dan C. Palm. 2001. Methods for Sampling Carbons Stocks Above and Below Ground. ASB Lecture note 4B. ICRAF, Bogor, Indonesia, $23 \mathrm{hlm}$.

Hartoko, A., Ignatius B., Hendrarto, \& Angela, M.D.W. 2013. Perubahan Luas Vegetasi Mangrove di Pulau Parang Kepulauan
Karimunjawa Menggunakan Citra Satelit. Journal of Management Aquatic Resources. 2(2):19-27

Imiliyana, A., Muryono, M. \& Purnobasuki, H.E.R.Y., 2012. Estimasi stok karbon pada tegakan pohon Rhizophora stylosa di pantai Camplong, Sampang-Madura. Skripsi. Fakultas Matematika dan Ilmu Pengetahuan Alam. Institut Teknologi Sepuluh November.

Kartijono, N.E., Rahayuningsih, M. \& Abdullah, M., 2010. Keanekaragaman Jenis Vegetasi dan Profi L Habitat Burung di Hutan Mangrove Pulau Nyamuk Taman Nasional Karimunjawa. Biosaintifika: Journal of Biology \& Biology Education, 2(1):27-39. doi: 10.15294/biosaintifika.v2i1.1149

Kitamura, S., Anwar, C., Chaniago, A., \& Baba, S. 1997. Handbook of mangrove in Indonesia: Bali dan Lombok. International Society for Mangrove Ecosystem. $119 \mathrm{hlm}$

Komiyama, A., Poungpam, S., \& Kato, S. 2005. Common Allometric Equations for Estimating The Tree Weight of Mangroves. Journal of Tropical Ecology. 21:471-477

Kennish, M.J. 1990. Ecology of Estuaries: Biological Aspect Vol II. CRS Press. New York. $465 \mathrm{hlm}$

Santini, N.S., Schmitz, N. \& Lovelock, C.E. Variation in wood density and anatomy in a widespread mangrove species. Trees 26: 1555 -1563. doi: 10.1007/s00468-012-0729-0.

Saparinto, C. 2007. Pendayagunaan Ekosistem Mangrove. Dahara Prize; Jakarta. $202 \mathrm{hlm}$. 